\title{
Langage, discours et techniques des Pygmées Aka de Centrafrique
}

Serge Bahuchet

\section{(2) OpenEdition \\ 12 Journals}

Édition électronique

URL : https://journals.openedition.org/tc/1044

DOI : $10.4000 /$ tc. 1044

ISSN : 1952-420X

Éditeur

Éditions de l'EHESS

\section{Édition imprimée}

Date de publication : 1 juin 1983

ISSN : 0248-6016

\section{Référence électronique}

Serge Bahuchet, «Langage, discours et techniques des Pygmées Aka de Centrafrique ", Techniques \& Culture [En ligne], 1 | 1983, mis en ligne le 26 janvier 2006, consulté le 29 septembre 2022. URL : http:// journals.openedition.org/tc/1044; DOI : https://doi.org/10.4000/tc.1044

Ce document a été généré automatiquement le 29 septembre 2022.

Tous droits réservés 


\section{Langage, discours et techniques des Pygmées Aka de Centrafrique}

Serge Bahuchet 